\title{
Health Risk Assessment due to Heavy Metals in Cow Pea Cultivated in Sanganer using Textile Waste Water
}

\author{
Jaishree $^{1}$, T. I. Khan ${ }^{2}$ \\ Indira Gandhi Centre for H.E.E.P.S., University of Rajasthan Jaipur, India
}

\begin{abstract}
The present study was carried out to estimate the concentration of heavy metals $(\mathrm{Zn} \mathrm{Cu}, \mathrm{Ni}, \mathrm{Cd}, \mathrm{Cr}, \mathrm{Pb}$ and $\mathrm{Co})$ in $\mathrm{Cow}$ pea (Vigna unguiculata) collected from different agricultural fields located in Sanganer, Jaipur. Atomic absorption spectrophotometer was used to determine the concentrations of heavy metals. The present study aims at determining human health risks associated with food chain contamination by heavy metals caused by industrial effluent water used in irrigation. The plants accumulated Zn concentration as high as $15.708 \mathrm{mg} / \mathrm{gm}, \mathrm{Cu} 8.878 \mathrm{mg} / \mathrm{gm}$, Ni $6.186 \mathrm{mg} / \mathrm{gm}, \mathrm{Cd} 5.446 \mathrm{mg} / \mathrm{gm}, \mathrm{Cr} 7.505 \mathrm{mg} / \mathrm{gm}, \mathrm{Pb} 6.595 \mathrm{mg} / \mathrm{gm} \mathrm{and} \mathrm{Co} 5.858 \mathrm{mg} / \mathrm{gm}$. Results revealed that the average concentrations of all metals in the cow pea was found in order of their abundance as $\mathrm{Zn}>\mathrm{Cu}>\mathrm{Cr}>$ $\mathrm{Pb}>\mathrm{Ni}>\mathrm{Co}>\mathrm{Cd}$.
\end{abstract}

Keywords: Textile waste water, Heavy metals, Health risk, Transfer Factor

\section{Introduction}

Heavy metals enter into food from natural sources like soil, air and water through wastewater irrigation, solid waste disposal, mining, smelting, sludge applications, vehicular exhaust, fertilizers, fungicides and industrial activities. (Muhammad et al, 2008, Radwan and Salama, 2006). Consumption of food crops contaminated with heavy metals is a major food chain route for human exposure. (Khan et al, 2008). The absorption of heavy metals in the system varies to certain extent depending on various factors. Heavy metals, in general, are nonbiodegradable, have long biological half-lives and have the potential for accumulation in the different body organs leading to acute as well as chronic toxic effects. (Radwan and Salama, 2006). The problem of heavy metal contamination is getting serious all in different countries of the world especially in developing countries. Moreover as heavy metal bio-accumulation increases in nutrition deprived state, developing countries with higher prevalence of under nutrition are at a greater risk of heavy metal toxicity. The contamination of heavy metals in agricultural soils can pose health problems which is a matter of concern. Therefore, there is the need to investigate the possible risks in the population due to the chronic exposure of heavy metal contamination in vegetables and fruits. Vegetables are common diet taken by populations throughout the world, being sources of essential nutrients, antioxidants and metabolites.(Thomsan and Kelly, 1990). Both essential and toxic elements are present in vegetables over a wide range of concentrations as they are said to be good absorber of metals from the soil (Lokeshwari and Chandrappa, 2006 and Eslami et,al. 2007). Vegetables absorb these metals from contaminated soils as well as from polluted environmental deposits through the roots and incorporate them into the edible part of plant tissues or deposit on the surface of vegetables. (Haiyan and Stuanes,2003, Nawaeji,2009).

In the present study Sanganer, Jaipur has been selected as study area where textile waste water drains into Amanishah nalla. The waste water is drawn through pumps and agricultural fields are irrigated with this untreated waste water.

\section{Study Area}

Sanganer, Jaipur was selected as study area. It is famous for Tie, dye and printing, waste paper recycling and blue pottery industries. Sanganer is located between $26^{\circ} 49^{\prime}$ to $26^{\circ} 51^{\prime} \mathrm{N}$ latitude and $75^{\circ} 46^{\prime}$ to $75^{\circ} 51^{\prime} \mathrm{E}$ longitude.(Fig 1). These industries discharge untreated waste water in Amanishah Nala(Earstwhile Dravyawati river) in Sanganer.(Fig 2). A large number of small, medium and large scale textile industrial units are located in Sanganer. The untreated waste water which contains chemicals like anelin, caustic soda, acids, bleaching powder and heavy metals is lifted through pumps and utilized in irrigating agricultural fields for growing vegetables and other crop plants.(Fig 3). 
International Journal of Science and Research (IJSR)

ISSN (Online): 2319-7064

Index Copernicus Value (2013): 6.14 | Impact Factor (2014): 5.611

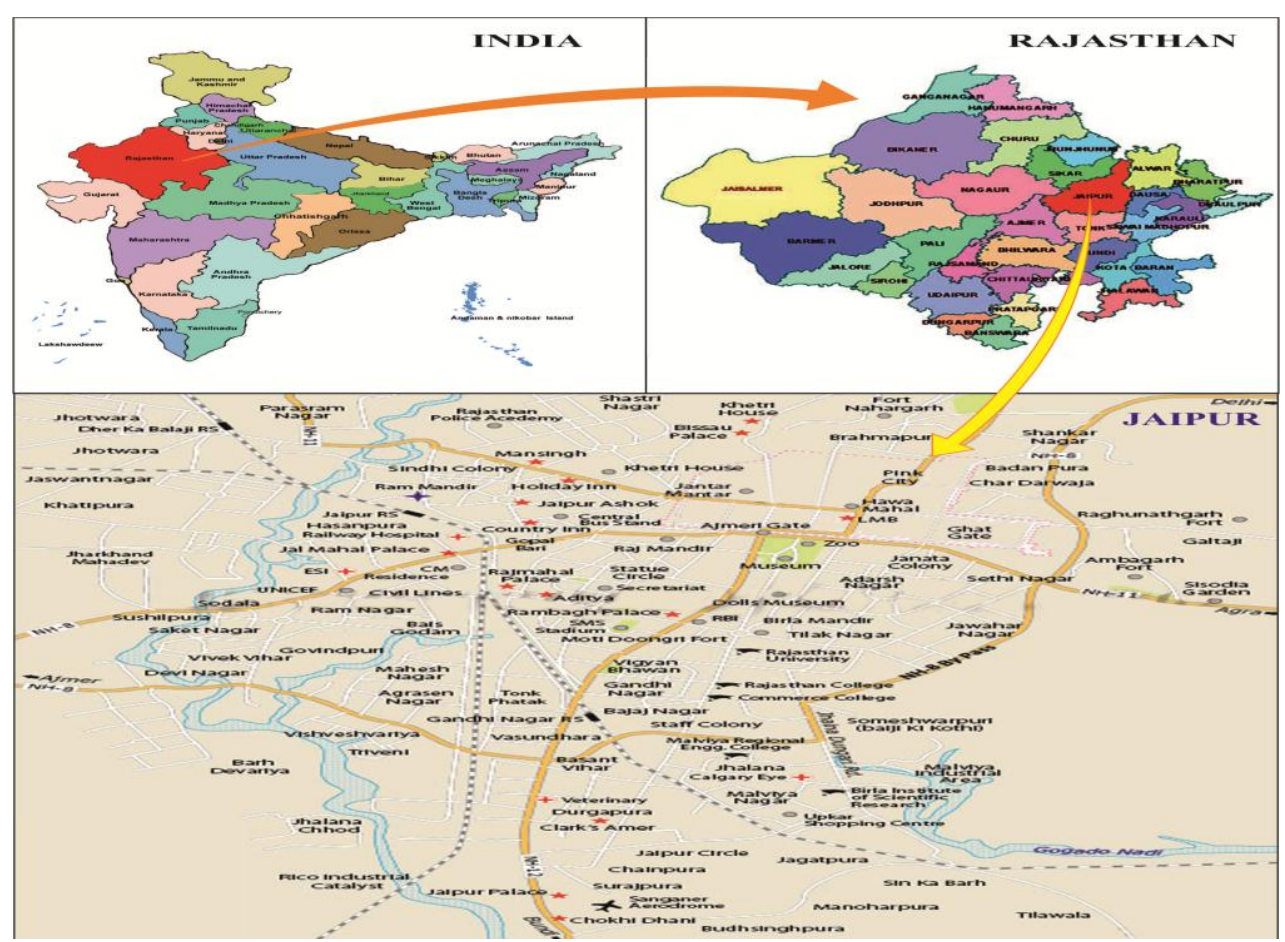

Figure 2: Showing Study area, Sanganer, Jaipur, Rajasthan, India.

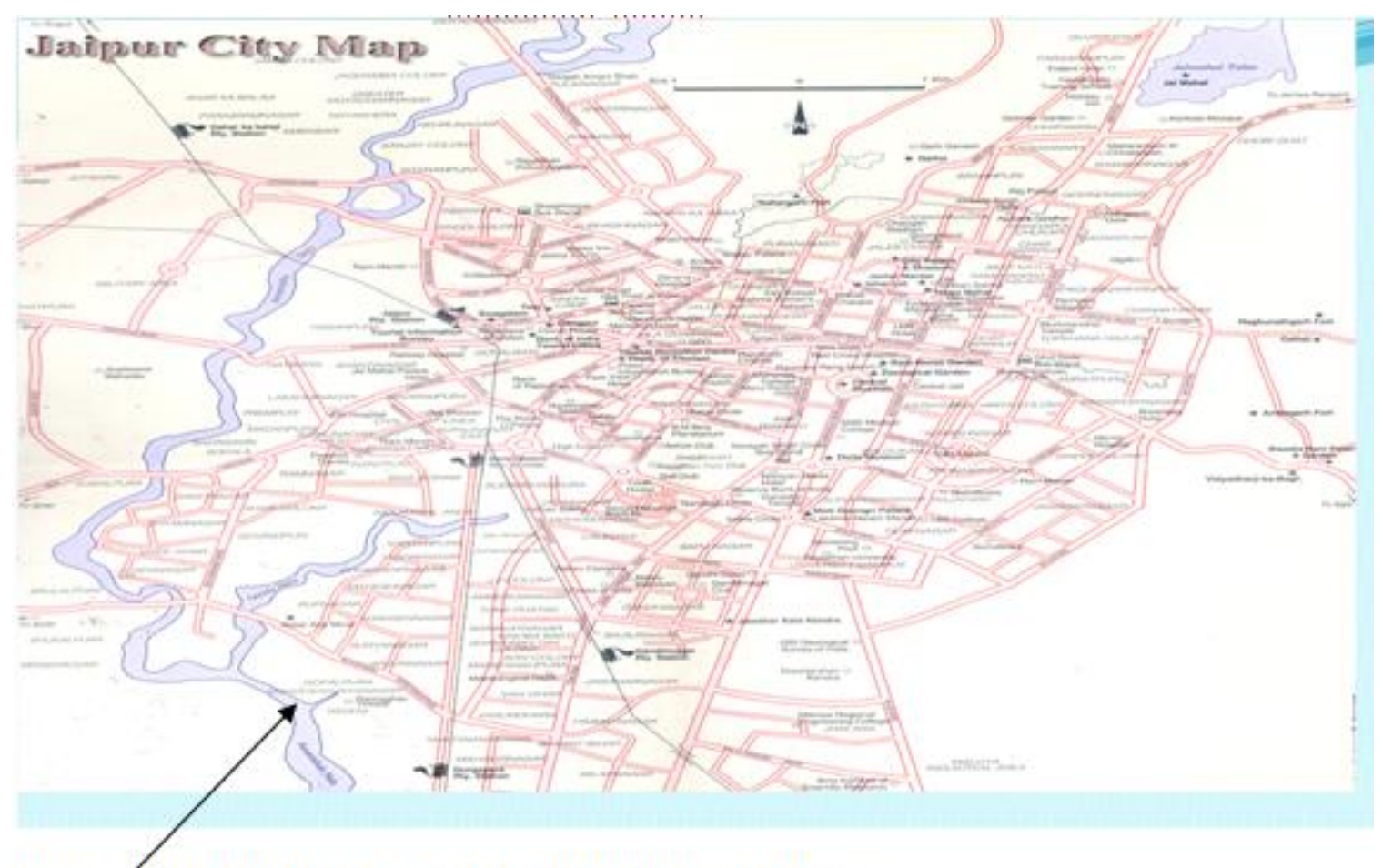

Waste water drained into Amanishah Nalla (Drayyawati river)

Figure 2: Showing Amanishah nalla 


\section{International Journal of Science and Research (IJSR) \\ ISSN (Online): 2319-7064}

Index Copernicus Value (2013): 6.14 | Impact Factor (2014): 5.611

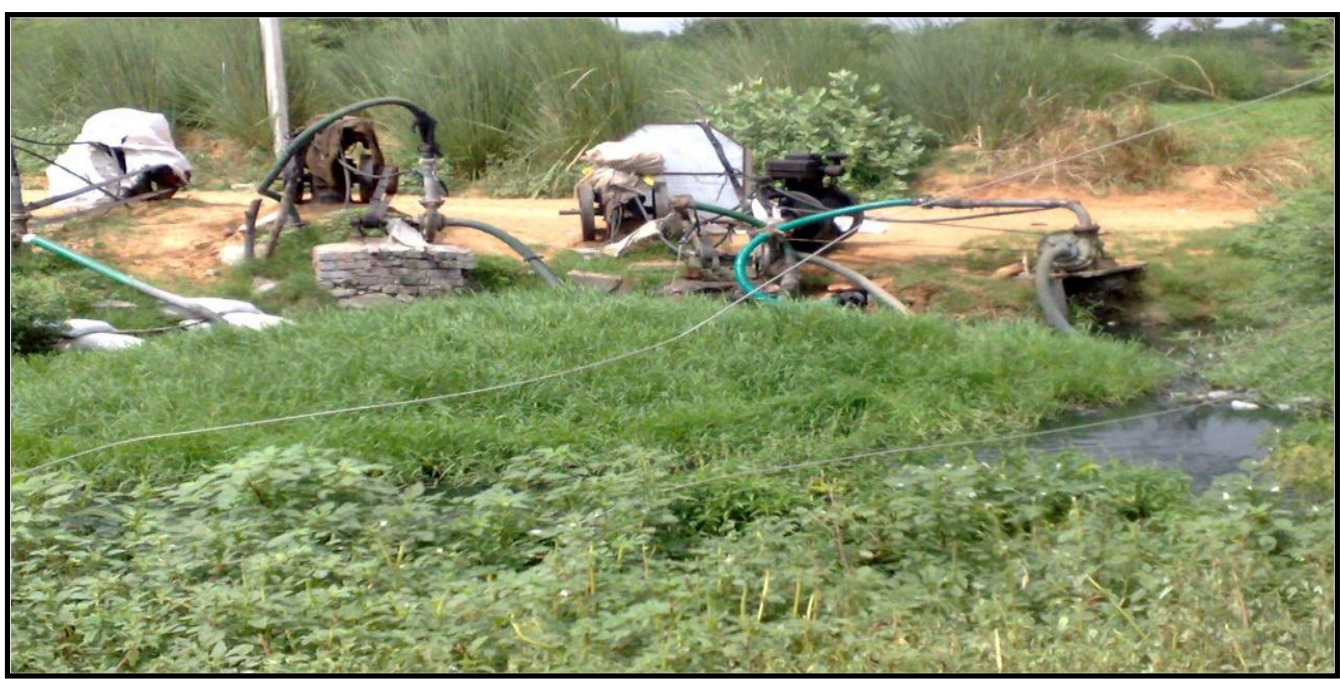

Figure 3: Series of pump sets, which is used to pump waste water for irrigating agricultural fields shown in the background.

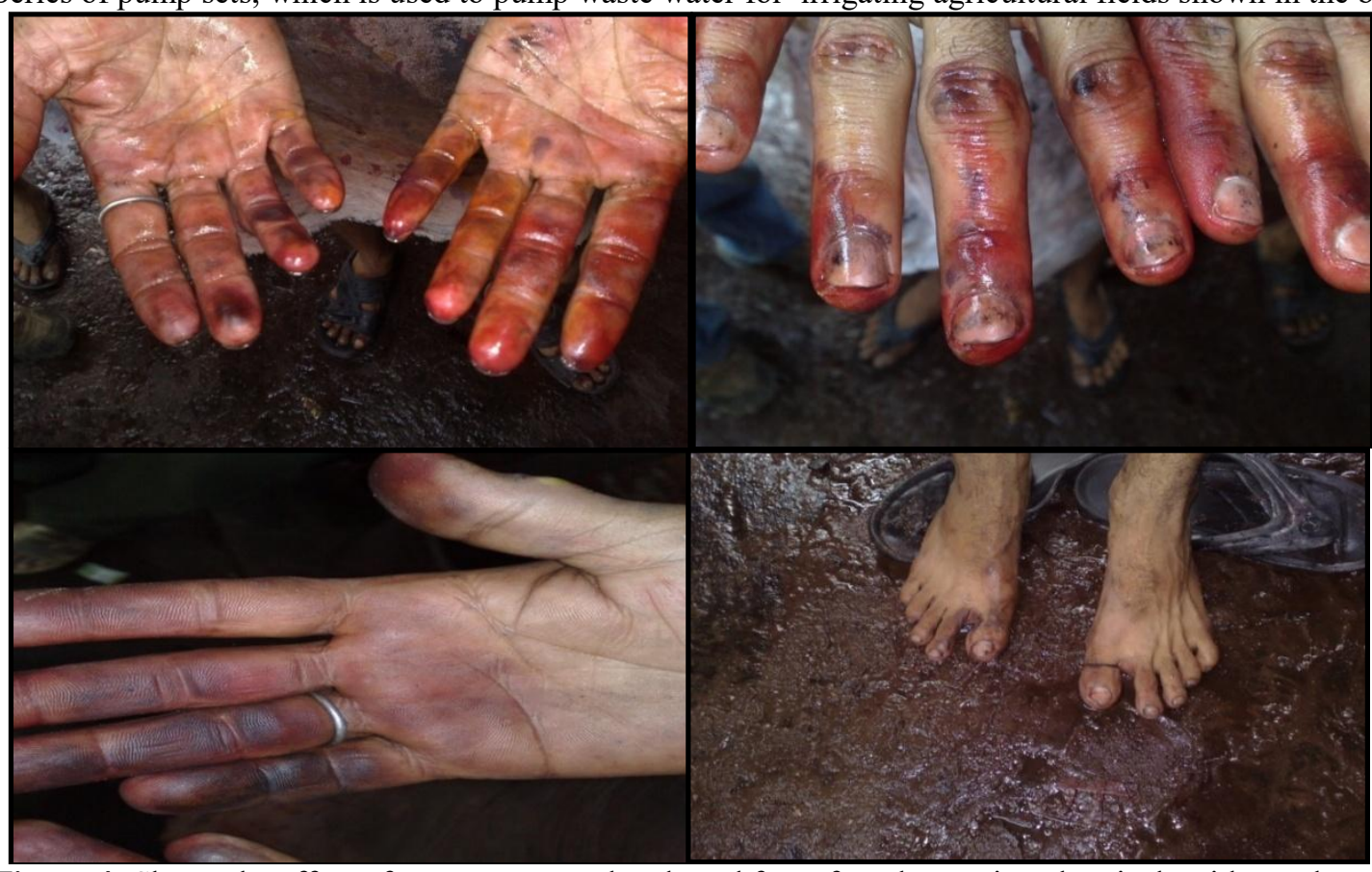

Figure 4: Shows the effect of waste water on hands and feet of workers using chemicals without gloves

\section{Material and Methods}

\section{Heavy Metal Analysis By Atomic Absorption Spectrophotometer \\ Atomic absorption Spectrophotometer (AAS Model GBC 932) was used for analysis of heavy metals in water. The $25 \mathrm{ml}$ of the sample was digested in di acid mixture of $\mathrm{HNO} 3$ and per chloric acid in the ratio of (10:1). The digestion was performed in $100 \mathrm{ml}$ conical flasks and to facilitate complete digestion the samples in di acid mixture were kept overnight at room temperature .These flasks containing samples and di acid mixture were heated at hot plate until a clear solution was obtained This was followed by a slow but complete evaporation of acids. Then, the volume of the digested samples was made up to $100 \mathrm{ml}$ with the help of the double distilled water .Finally these solutions were analyzed by Atomic Absorption Spectrophotometer.}

\section{Data Analysis}

\section{Transfer Factor (TF)}

Soil to plant metal transfer was computed as transfer factor(TF), which was calculated by using the equation $\mathrm{TF}=\mathrm{C}_{\text {PLANT }} / \mathrm{C}_{\text {SOIL }}$

where, C Plant is the concentration of heavy metals in plants and $\mathrm{C}$ Soil is the concentration of heavy metals in soil.

\section{Daily Intake of Metals (DIM)}

Daily intake of vegetables in adult was calculated by data obtained during the survey though a questionnaire. DIM was calculated by the following equation suggested by Chary et al., (2008).

$\mathrm{DIM}=\mathrm{C}_{\text {metal }} \times \mathrm{C}_{\text {factor }} \times \mathrm{D}_{\text {food intake }} / \mathrm{B}_{\text {average weight }}$

where, $\mathrm{C}_{\text {metal }}, \mathrm{C}_{\text {factor }}, \mathrm{D}_{\text {food intake }}, \mathrm{B}_{\text {average weight }}$ represent the heavy metal concentrations in plants $\left(\mathrm{mg} \mathrm{kg}^{-1}\right)$, conversion factor (0.085), daily intake of vegetables and average body weight, respectively. The average vegetable intake was 


\section{International Journal of Science and Research (IJSR) \\ ISSN (Online): 2319-7064}

Index Copernicus Value (2013): 6.14 | Impact Factor (2014): 5.611

calculated by conducting a survey where about 200 people (males and females) having an average body weight of $48 \mathrm{~kg}$ were asked for their daily intake of particular vegetables from sampling sites.

\section{Health Risk Index (HRI)}

To assess the human health risk of heavy metals, it is necessary to calculate the level of human exposure to that metal by tracing the route of exposure of pollutant to human body. There subsist many exposures routes for heavy metals that depend upon a contaminated media of soil and vegetables on the recipients. Receptor population use the vegetables enriched with higher concentration of heavy metals which enters the human body leading to health risks (Khan et,al. 2008). In the present research work vegetables grown at the wastewater were collected from the study area and their metal concentration was used to calculate the health risk index (HRI). The health risk index of the present research work was compared with the one reported by Khan et al. (2008) and Jan et al(2010). Results of HRI were found to be lower than those of Khan et al.(2008) and Jan et al.(2010). Value of HRI depends upon the daily intake of metals (DIM) and oral reference dose $\left(R_{\mathrm{fd}}\right) \cdot \mathrm{R}_{\mathrm{fd}}$ is an estimated per day exposure of metal to the human body that has no hazardous effect during life time [USEPA 2006].The health risk index for $\mathrm{Cr}, \mathrm{Ni}, \mathrm{Cu}, \mathrm{Pb}, \mathrm{Cd}, \mathrm{Mn}$ and $\mathrm{Zn}$ by consumption of contaminated vegetables was calculated by following equation -

\section{$\mathrm{HRI}=\mathrm{DIM} / \mathrm{R}_{\mathrm{fd}}$}

where DIM represents the daily intake of metals and $R_{f d}$ represents reference oral dose. $\mathrm{R}_{\mathrm{fd}}$ for $\mathrm{Cr}, \mathrm{Ni}, \mathrm{Cu}, \mathrm{Pb}, \mathrm{Cd}$, $\mathrm{Co}$ and $\mathrm{Zn}$ is $1.5,0.02,0.04,0.004,0.001,0.033$ and 0.30 ( $\mathrm{mg} / \mathrm{kg}$ bw/day) respectively .

\section{Result and Discussion}

Concentration of heavy metals in soil obtained from different agricultural sites of Sanagner was found to be significantly high. The concentration of heavy metals in soil were above the safe limits set by USEPA, WHO and Indian standards. (Awashthi 2000). The concentrations of heavy metals $(\mathrm{mg} / \mathrm{g})$ in agricultural soil collected from different crop production sites . $\mathrm{Zn}$ concentration varied from 11.758 $\mathrm{mg} / \mathrm{gm}$ to $16.495 \mathrm{mg} / \mathrm{gm}, \mathrm{Cu}$ concentration was from $11.013 \mathrm{mg} / \mathrm{gm}$ to $11.589 \mathrm{mg} / \mathrm{gm}, \mathrm{Ni}$ was from $4.623 \mathrm{mg} / \mathrm{gm}$ to $5.011 \mathrm{mg} / \mathrm{gm}, \mathrm{Cd}$ varied from $4.586 \mathrm{mg} / \mathrm{gm}$ to 5.234 $\mathrm{mg} / \mathrm{gm}, \mathrm{Cr}$ concentration varied from $6.189 \mathrm{mg} / \mathrm{gm}$ to 6.998 $\mathrm{mg} / \mathrm{gm}, \mathrm{Pb}$ was from $5.286 \mathrm{mg} / \mathrm{gm}$ to $5.896 \mathrm{mg} / \mathrm{gm}$ and $\mathrm{Co}$ varied from $3.684 \mathrm{mg} / \mathrm{gm}$ to $3.912 \mathrm{mg} / \mathrm{gm}$. (Table 1).

Concentration of heavy metals in cow pea on a dry weight basis grown in wastewater. Concentration of heavy metals in Cow pea samples collected from different agricultural field sites. Results revealed that the heavy metal concentration was significantly higher in cow pea. The heavy metals were estimated in $\mathrm{mg} / \mathrm{gm}$ dry weight. The plants accumulated $\mathrm{Zn}$ concentration varied from 15.684 $\mathrm{mg} / \mathrm{gm}$ to $15.708 \mathrm{mg} / \mathrm{gm}, \mathrm{Cu}$ concentration varied from $8.348 \mathrm{~m} / \mathrm{gm}$ to $8.878 \mathrm{mg} / \mathrm{gm}$, Ni varied from $6.098 \mathrm{mg} / \mathrm{gm}$ to $6.186 \mathrm{mg} / \mathrm{gm}$, Cd concentration varied from $5.264 \mathrm{mg} / \mathrm{gm}$ to $5.446 \mathrm{mg} / \mathrm{gm}, \mathrm{Cr}$ was varied from $7.475 \mathrm{mg} / \mathrm{gm}$ to 7.505 $\mathrm{mg} / \mathrm{gm}, \mathrm{Pb}$ concentration varied from $6.567 \mathrm{mg} / \mathrm{gm}$ to6.595 $\mathrm{mg} / \mathrm{gm}$ and Co concentration was varied from $5.538 \mathrm{mg} / \mathrm{gm}$ to $5.858 \mathrm{mg} / \mathrm{gm}$.(Table 2$)$.

\section{Transfer Factor (TF), daily intake of metal(DIM) and health risk index(HRI) were also calculated}

Transfer factor for cow pea in different heavy metals $\mathrm{Zn}$ was $1.097, \mathrm{Cu}$ was0.764, $\mathrm{Ni}$ was $1.251, \mathrm{Cd}$ was $1.082, \mathrm{Cr}$ was 1.157 , Co was 1.481 and $\mathrm{Pb}$ was 1.179 . Plants uptake the heavy metals from soil and then it accumulate in different parts of plant.(Table 3).

Values of DIM calculated for adults (average age 48 years), are presented in this. These data revealed that the values of daily intake of metal were high for vegetables grown at different five agricultural sites. The trend for DIM in vegetables grown was in the order of $\mathrm{Zn}^{2+}>\mathrm{Cu}^{2+}>\mathrm{Cr}^{3+}$ $>\mathrm{Pb}^{2+}>\mathrm{Cu}^{2+}>\mathrm{Zn}^{2+}>\mathrm{Mn}^{2+}$. The highest value of DIM for $\mathrm{Zn}$ was $0.061 \mathrm{mg} / \mathrm{kg} /$ day and lowest value of DIM for Cd was $0.009 \mathrm{mg} / \mathrm{kg} /$ day.(Table 3).

To assess the health risk associated with heavy metal contamination of plants grown locally, estimated exposure and risk index were calculated. The results showed that $\mathrm{Cd}$, $\mathrm{Pb}$ and $\mathrm{Ni}$ contamination in plants had greatest potential to pose health risk to the consumers. HRI was maximum for $\mathrm{Cd}^{2+}$ in cow pea and minimum or out of danger for $\mathrm{Cr}^{2+}$. (Table 3).

Heavy metals causes different types of diseases $\mathrm{Zn}$ causes Stomach cramps, nausea, vomiting, anaemia, damage to the pancreas , Ni causes Stomach cramps, nausea, vomiting, anaemia, damage to the pancreas, $\mathrm{Pb}$ causes Haematological and cardiovascular effects (hypertension), kidney damage , $\mathrm{Cd}$ damage to kidneys and lungs, fragile bones, anaemia, increased risk of cancer if inhaled, Co affects the respiratory sensitization, asthma, shortness of breath, and decreased pulmonary function, Cr causes Skin rashes ,Upset stomachs and ulcers, Respiratory problems, weakened immune systems, Kidney and liver damage ,Alteration of genetic material ,Lung cancer and $\mathrm{Cu}$ causes the hematological manifestations, such as myelodysplasia , ananemia , leukopenia (low white blood cell count) and neutropenia (low count of neutrophils, a type of white blood cell that is often called "the first line of defense" for the immune system). Vegetables take up metals by absorbing them from contaminated soils, as well as from deposits on different parts of the vegetables exposed to the air from polluted environments (Sobukola et al., 2010). Prolonged human consumption of unsafe concentrations of heavy metals in food stuffs may lead to the disruption of many biological and biochemical processes in the human body (WHO, 1993; Jarup, 2003). Intake of vegetables is an important path of heavy metal toxicity to human being. Dietary intake of heavy metals through contaminated vegetables may lead to various chronic diseases.A number of serious health problems can develop as a result of excessive uptake of dietary heavy metals.(Arora et,al.2008). Furthermore, the consumption of heavy metal-contaminated food can seriously deplete some essential nutrients in the body causing a decrease in immunological defenses, intrauterine growth retardation, impaired psycho- social behaviors, 


\section{International Journal of Science and Research (IJSR) \\ ISSN (Online): 2319-7064}

Index Copernicus Value (2013): 6.14 | Impact Factor (2014): 5.611

disabilities associated with malnutrition and a high prevalence of upper gastrointestinal cancer .

Table 1: Concentration of Heavy metals in soil

\begin{tabular}{|l|c|c|c|c|c|c|c|}
\hline \multirow{2}{*}{ SITES } & \multicolumn{7}{|c|}{ Heavy metals(mg/gm) } \\
\cline { 2 - 8 } & $\mathbf{Z n}$ & $\mathbf{C u}$ & Ni & Cd & Cr & Pb & Co \\
\hline Site 1 & 13.289 & 11.125 & 5.011 & 4.586 & 6.378 & 5.896 & 3.684 \\
\hline Site 2 & 15.236 & 11.589 & 4.789 & 4.865 & 6.189 & 5.286 & 3.712 \\
\hline Site 3 & 16.495 & 11.445 & 4.623 & 4.912 & 6.245 & 5.895 & 3.776 \\
\hline Site 4 & 11.758 & 11.512 & 5.121 & 5.019 & 6.539 & 5.319 & 3.845 \\
\hline Site 5 & 14.698 & 11.013 & 4.948 & 5.234 & 6.998 & 5.489 & 3.912 \\
\hline
\end{tabular}

Table 2: Concentration of Heavy metals in Vigna unguiculata (cow pea)

\begin{tabular}{|l|c|c|c|c|c|c|c|}
\hline \multirow{2}{*}{ SITES } & \multicolumn{7}{|c|}{ Heavy metals(mg/gm) } \\
\cline { 2 - 8 } & $\mathrm{Zn}$ & $\mathrm{Cu}$ & $\mathrm{Ni}$ & $\mathrm{Cd}$ & $\mathrm{Cr}$ & $\mathrm{Pb}$ & $\mathrm{Co}$ \\
\hline Site 1 & 15.708 & 8.742 & 6.109 & 5.264 & 7.475 & 6.575 & 5.538 \\
\hline Site 2 & 15.690 & 8.348 & 6.123 & 5.289 & 7.487 & 6.579 & 5.546 \\
\hline Site 3 & 15.684 & 8.568 & 6.098 & 5.312 & 7.490 & 6.567 & 5.548 \\
\hline Site 4 & 15.696 & 8.796 & 6.142 & 5.348 & 7.501 & 6.583 & 5.553 \\
\hline Site 5 & 15.689 & 8.878 & 6.186 & 5.446 & 7.505 & 6.595 & 5.858 \\
\hline
\end{tabular}

Table 3: Transfer Factor, Daily Intake of Metal and Health Risk Index:-

\begin{tabular}{|c|c|c|c|c|}
\hline $\begin{array}{c}\text { Heavy } \\
\text { metals }\end{array}$ & $\begin{array}{c}\text { Average concentration } \\
\mathrm{mg} / \mathrm{gm}\end{array}$ & $\begin{array}{c}\text { Transfer } \\
\text { Factor }\end{array}$ & H.R.I & $\begin{array}{c}\text { D.I.M } \\
(\mathrm{mg} / \mathrm{kg} / \text { day }\end{array}$ \\
\hline $\mathrm{Zn}$ & 15.689 & 1.097 & 0.203 & 0.061 \\
\hline $\mathrm{Cu}$ & 8.666 & 0.764 & 0.85 & 0.034 \\
\hline $\mathrm{Ni}$ & 6.131 & 1.251 & 0.5 & 0.010 \\
\hline $\mathrm{Cd}$ & 5.331 & 1.082 & 9 & 0.009 \\
\hline $\mathrm{Cr}$ & 7.491 & 1.157 & 0.019 & 0.029 \\
\hline $\mathrm{Pb}$ & 6.579 & 1.179 & 3 & 0.012 \\
\hline $\mathrm{Co}$ & 5.608 & 1.481 & 0.242 & 0.008 \\
\hline
\end{tabular}

\section{Conclusion}

In this present study it is conducted that continuous wastewater irrigation in the agricultural land has caused an ample build up of toxic metals. Food items analysis and monitoring should be performed in order to prevent excessive build up of these heavy metals in the food chain. Variations in the heavy metal concentrations between the test vegetables/cereal crops reflect the differences in uptake capabilities and their further translocation to the edible portion of the plants. Heavy metals have a toxic impact, but detrimental impacts become apparent only when long term consumption is done. Consumption of foodstuff with elevated levels of heavy metals may lead to high level of accumulation in the body causing related health disorders. It is suggested that waste water should be used only after adequate treatment.

\section{Acknowledgement}

The authors are thankful to the Director, Indira Gandhi Centre for Human Ecology, Environment and Population Studies and Dean Faculty of Science, University of Rajasthan for providing necessary facilities. One of the authors (Jaishree) is thankful to University Grant Commission New Delhi for providing financial assistance as Rajiv Gandhi Senior Research Fellowship.
[1] Awashthi, S.K. 2000. Prevention of food adultration Act no. 37 of 1954. Centre and State rules as amended for $1999,3^{\text {rd }}$ edn, Ashoka Law House, New Delhi.

[2] Chary, N.S., Kamala, C.T., Raj, D.S.S., 2008. Assessing risk of heavy metals from consuming food grown on sewage irrigated soils and food chain transfer. Ecotoxicol. Environ. Safety 69, 513-524.

[3] Eslami, A., Khaniki, Gh.R.J., Nurani, M., Meharasbi, M., Peyda, M. and Azimi, R. 2007. Heavy metals in edible green vegetables grown along the sites of the Zanjan roads Iran. Journal of Biological Sciences. 7: 943-948.

[4] European Union, 2002. Heavy Metals in Wastes, European Commission on Environment. $<$ http://ec.europa.eu/environment/waste/studies/pdf/ heavymetalsreport.pdf $>$.

[5] Haiyan, W. and Stuanes, A. 2003. Heavy metal pollution in air-water-soil-plant system of Zhuzhou city, Hunan province, China. Water, Air and Soil Pollution. 147: 79-107.

[6] Jan, F.A., Ishaq, M., Khan, S., Ihsanullah, I., Ahmad, I., Shakirullah, M., 2010. A comparative study of human health risks via consumption of food crops grown on wastewater irrigated soil (Peshawar) and relatively clean water irrigated soil (lower Dir). J. Hazard. Mater. 179, 612-621.

[7] Jarup, L. (2003): Hazards of heavy metal contamination, Br. Med. Bull. 68, 167-182.

[8] Khan S., Cao Q., Zheng Y., Huang Y. and Zhu Y.,(2008). Health risks of heavy metals in contaminated soils and food crops irrigated with wastewater in Beijing, China .J of Science of Food and Agriculture. 1997 (73):446-454 .

[9] Khan, S., Cao, Q., Zheng, Y.M., Huang, Y.Z. and Zhu, Y.G.2008. Health risks of heavy metals in contaminated soils and food crops irrigated with wastewater in Beijing, China. Environmental Pollution. 152 : 686-692.

[10] Lokeshwari, H. and Chandrappa, G.T. 2006. Impact of heavy metal contamination of Bellandur Lake on soil and cultivated vegetation. Current Science. 91: 622627.

[11] Muhammad F., Farooq A. and Umer R., Appraisal of heavy metal contents in different vegetables grown in the vicinity of an industrial area, Pakistan Journal of Botany, 40(5), 2099-2106 (2008).

[12] Nwajei, G.E. 2009. Trace elements in soils and vegetations in the vicinity of shell Petroleum Development Company operating area in Ughelli, delta state of Nigeria. American Eurasian. Journal of Sustainable Agriculture. 3: 574-578.

[13] Radwan A. and Salama A.(2006). Market basket survey for some heavy metals in Egyptian fruits and vegetables, Food and Chemical Toxicology. 44, 1273-1278 .

[14] Sobukola, O.P., Adeniran, O.M., Odedairo, A.A., Kajihausa, O.E. (2010): Heavy metal levels of some fruits and leafy from selected markets in Lagos, Nigeria vegetables, Afr. J. Food Sci. 4 (2), 389393.

[15] Thompson, H.C. and Kelly, W.C. 1990. Vegetable Crops. $5^{\text {th }}$ Edn., McGraw Hill Publishing Company Ltd., New Delhi.

\section{References}




\section{International Journal of Science and Research (IJSR) \\ ISSN (Online): 2319-7064}

Index Copernicus Value (2013): 6.14 | Impact Factor (2014): 5.611

[16]US-EPA, IRIS. United States, Environmental Protection Agency, Integrated Risk Information System.http://www.epa.gov/iris/subst(December, 2006).

[17] WHO (World Heath Organization). Evaluation of certain food additives and contaminants. 41st Report of the Joint FAO/WHO Expert Committee on Food Additives. Technical Report Series. Geneva: WHO, 1993. 